\title{
Distribution of luminescent Vibrio harveyi and their bacteriophages in a commercial shrimp hatchery in South India
}

\author{
B. Chrisolite, S. Thiyagarajan ${ }^{1}$, S.V. Alavandi *, E.C. Abhilash, N. Kalaimani, \\ K.K. Vijayan ${ }^{2}$, T.C. Santiago \\ Central Institute of Brackishwater Aquaculture, (Indian Council of Agricultural Research), \\ 75, Santhome High Road, Raja Annamalai Puram, Chennai-600 028 India
}

Received 18 May 2007; received in revised form 19 November 2007; accepted 14 December 2007

\begin{abstract}
Luminescent Vibrio harveyi is a natural microflora of marine and coastal water bodies and is associated with mortality of larval shrimp in penaeid shrimp hatcheries. It is also known that the bacteriophages occur virtually in all places where their hosts exist. In this study, distribution of luminescent $V$. harveyi and the bacteriophages affecting these hosts was examined in a commercial Penaeus monodon hatchery during three shrimp larval production cycles, including a cycle affected by luminescent bacterial (LB) disease outbreak.

Out of a total of 1195 samples drawn from seawater source, sand-filtered water, nauplius, zoea, mysis and post larval rearing tanks, maturation and spawning tanks, Artemia hatching tank and algal culture tanks processed using conventional microbiological techniques, $21.4 \%$ of the samples harboured luminescent bacteria. During the larval production cycle affected by LB disease (LBD), luminescent $V$. harveyi could be recovered from $52 \%$ of the hatchery samples, whereas during luminescent bacterial disease-free larval production cycle (LBDF), these bacteria could be recovered from only about $9 \%$ of the samples. The predominant source of luminescent bacteria was the brood shrimp and their rearing tanks in maturation and spawning facilities. $73 \%$ of the maturation and $80 \%$ of the spawning tank water samples harbored LB during LBD, whereas, only $20 \%$ and $32 \%$ of the maturation and spawning tanks respectively harbored LB during LBDF. LB could be isolated from $17 \%$ of the water samples in tanks from nauplius stage onwards with increasing counts that subsequently lead to LB disease.

Bacteriophages affecting the luminescent $V$. harveyi could be isolated from as many as $36 \%(21 \%$ and $43 \%$ of the samples analysed during LBDF and LBD respectively) of a total of 181 water samples drawn from various sources in the hatchery, using 27 luminescent $V$. harveyi hosts by agar overlay technique. The maturation tank water samples were found to be the predominant source of bacteriophages, followed by spawning tank water samples as observed with the LB. Sixty five bacteriophages, 13 during LBDF and 52 during LBD were isolated, which were grouped in to seven types based on their plaque morphology.

The study has indicated that the brooders, maturation and spawning facilities in the shrimp hatchery are the main source of luminescent $V$. harveyi and their bacteriophages and that occurrence of LB even in low counts during early larval stages can possibly lead to development of LB disease despite presence of bacteriophages in the larval rearing tanks.
\end{abstract}

(C) 2007 Elsevier B.V. All rights reserved.

Keywords: Bacteriophages; Luminescent bacteria; Vibrio harveyi; Penaeus monodon; Shrimp hatchery

* Corresponding author.

E-mail address: svalavandi@yahoo.com (S.V. Alavandi).

${ }^{1}$ Tel.: +91 44 24618817; fax: +91 4424610311 .

2 Present address: Head, Nutrition, Physiology and Pathology Division, Central Marine Fisheries Research Institute, Post Box No. 1603, Ernakulam North PO, Kochi 682 018, India.

\section{Introduction}

The luminescent Vibrio harveyi has been reported to be one of the major causes of mass mortality of larval stages in penaeid shrimp hatcheries throughout the world (Sunaryanto and Mariam, 1986; Lavilla-Pitogo et al., 1990; Karunasagar et al., 1994; Jiravanichpaisal et al., 1994; Pizzutto and Hirst, 1995; 
Liu et al., 1996; Alvarez et al., 1998). Luminescent bacteria (LB) are ubiquitous in the marine environment and are abundant in sea water (Yetinson and Shilo, 1979), surface and gut of marine animals (O' Brien and Sizemore, 1979; Ruby and Morin, 1979). A number of reports exist on their distribution in the marine environment (Ramaiah and Chandramohan, 1993), shrimp grow out ponds and hatcheries (Karunasagar et al., 1994; Abraham and Palaniappan, 2004). In a recent study in Tamil Nadu, India, based on the analysis of a large number of samples from maturation and spawning tanks, larval rearing tanks, Artemia and algal culture tanks it was reported that, the gut of shrimp brooders was the predominant source of LB (Abraham and Palaniappan, 2004). However, the study did not relate the occurrence of LB with the outbreak of LB disease in the larval stages during the hatchery operation.

Control of luminescent bacterial disease using antibiotics was reported to be effective in laboratory trials (Baticados et al., 1990) while their efficacy in field conditions are reportedly very low (Moriarty, 1999). Further, use of antibiotics in the hatcheries has led to the emergence of resistant strains of bacteria (Karunasagar et al., 1994). Bacteriophages, the viruses that infect and kill their specific hosts, have been reported to offer scope as an alternative to antibiotics as therapeutic agents in controlling bacterial infections (Sulakvelidze et al., 2001) and the concept of phage therapy has been explored by some investigators in aquaculture (Nakai and Park, 2002). Bacteriophages can be found in virtually all places where their hosts exist (Ackermann, 1996) and the host cells are the main resource for their proliferation and life cycle (Weinbauer, 2004). Bacteriophages are also known to play an important role in prokaryotic predation and controlling bacterial populations in the aquatic ecosystems (Weinbauer, 2004; Proctor and Fuhrman, 1990). It is estimated that the viral load in the coastal ecosystems are of the order of $10^{8}$ viruses per ml (Suttle, 2005) and about $10-20 \%$ of the heterotrophic bacteria are lost per day due to viral infection (Suttle, 1994). Bacteriophages specifically infecting bacterial pathogens of finfish such as Lactococcus garviae and Pseudomonas plecoglossicida have been reported earlier (Park et al., 1997; Park et al., 2000). Isolation of bacteriophages of $V$. harveyi has been recently reported by Pasharawipas et al. (2005) and Vinod et al. (2006). However information on the distribution of bacteriophages of $V$. harveyi and their role in situ in the shrimp hatchery ecosystem is scanty.

The objective of the present study was to understand the distribution of luminescent bacteria and their associated bacteriophages during shrimp larval production cycles in a commercial shrimp hatchery during various stages of seed production and to understand the role of in situ population of bacteriophages in containment of luminescent $V$. harveyi and LB disease.

\section{Materials and methods}

\subsection{Sample collection, isolation and identification of $V$. harveyi}

Samples were collected from a commercial Penaeus monodon hatchery located $20 \mathrm{~km}$ north of Pondicherry, south east coast of India, during three cycles of seed production, two of which were free from luminescent bacterial disease (LBDF) and one cycle had an outbreak of luminescent bacterial disease (LBD) in the mysis-PL stages. Water samples from seawater source, sand-filtered water, nauplius, zoea, mysis and post larval rearing tanks, maturation and spawning tanks, Artemia hatching tanks and algal (Skeletonema sp.) culture tanks were collected in sterile polypropylene containers. Swab samples of brooders' body surface, gills, intestine and faecal matter were also collected for microbiological analysis. Weighed samples of gills, intestine and faecal matter were processed to obtain LB counts per unit weight of the sample. Luminescent bacterial count was determined using Luminescence agar medium (Schneider and Rheinheimer, 1988) and V. harveyi selective medium (Harris et al., 1996) by serial dilution and spread plate technique. Luminescent colonies on Luminescence agar medium and dark green centered colonies with yellow halo on Harris' medium were purified on Trypticase Soya Agar (TSA) (Himedia, Mumbai, India) and subjected to a series of phenotypic and biochemical tests such as grams stain, motility, salt tolerance $(0 \%, 3 \%, 6 \% 8 \%$ and $10 \%)$, amino acid decarboxylation (arginine, lysine and ornithine), production of indole, methyl red and acetyl methyl carbinol, and sugar fermentation (glucose, sucrose, arabinose, mannitol and cellobiose) (Smibert and Krieg, 1991). The isolates were identified using the keys described by Alsina and Blanch (1994), and Baumann and Schubert (1984).

\subsection{Isolation of bacteriophages of luminescent $V$. harveyi}

Water samples from seawater source, spawning and maturation tanks and larval rearing tanks were processed for isolation of bacteriophages of luminescent $V$. harveyi by overlay agar technique (Suttle, 1993). Twenty-seven isolates of luminescent $V$. harveyi, were used as hosts for the isolation of bacteriophages. Ten $\mathrm{ml}$ of water samples collected from these sources in sterile polypropylene tubes were centrifuged at $10,400 \mathrm{~g}$ at $4{ }^{\circ} \mathrm{C}$, and the supernatant was filtered through $0.45 \mu \mathrm{m}$ filter (Millipore, Bedford, USA). One $\mathrm{ml}$ of this filtrate was used as phage sample and mixed with $0.1 \mathrm{ml}$ of $\log$ phase cultures $\left(\mathrm{OD}_{600}=0.3\right)$ of $V$. harveyi hosts grown in Tryptone soya broth (TSB, Himedia, Mumbai, India) and incubated at $30^{\circ} \mathrm{C}$ for $30 \mathrm{~min}$. After incubation, $5 \mathrm{ml}$ of molten soft agar (TSB with $1.5 \%$ $\mathrm{NaCl}, 0.3 \%$ glycerol and $0.7 \%$ agar) held at $46{ }^{\circ} \mathrm{C}$ in a water bath was added, mixed and overlaid on TSA supplemented with $1.5 \% \mathrm{NaCl}$ and $0.3 \%$ glycerol. The plates were incubated at $30{ }^{\circ} \mathrm{C}$ for $18-24 \mathrm{~h}$ and observed for the presence of plaques. The plaques were counted and expressed as plaque forming unit per $\mathrm{ml}\left(\mathrm{pfu} \mathrm{m}^{-1}\right)$. $10-20$ of these plaques were suspended in $1 \mathrm{ml}$ sterile SM buffer (Tris $\mathrm{HCl} 0.05 \mathrm{M}$, $\mathrm{pH} 7.4, \mathrm{NaCl} 0.1 \mathrm{M}, \mathrm{MgSO}_{4} 10 \mathrm{mM}$, gelatin $1 \% \mathrm{w} / \mathrm{v}$ ) (Carlson, 2005) and centrifuged at $10,400 \mathrm{~g}$ for $10 \mathrm{~min}$ at $4{ }^{\circ} \mathrm{C}$ and filtered through $0.45 \mu \mathrm{m}$ filter. The filtrate was added to $10 \mathrm{ml}$ broth culture of the respective host strain growing at log phase and incubated at $30{ }^{\circ} \mathrm{C}$ for $24 \mathrm{~h}$. After incubation the suspension was centrifuged at $10,400 \mathrm{~g}$ for $10 \mathrm{~min}$. The supernatant was filtered through $0.45 \mu \mathrm{m}$ filter and aliquots were stored at $-70{ }^{\circ} \mathrm{C}$ with $50 \%$ glycerol for further studies.

\section{Results}

\subsection{Distribution of luminescent bacteria}

Luminescent bacteria could be isolated from as high as $52 \%$ of the 338 samples comprising hatchery seawater source, brooders, maturation and spawning tanks, algal culture tanks and larval rearing tanks during the shrimp seed production cycle affected by LB disease during mysis stage. Recovery of LB was far lower (9\%) among the 857 samples analysed during the two shrimp seed production cycles free from LB disease (Table 1). Very low counts of LB (20-230 cfu ml ${ }^{-1}$ ) could be found in hatchery seawater source and sand-filtered water samples (4/25 and $1 / 25$ respectively) during the cycle that subsequently developed LB disease, whereas, none of 45 each of these seawater source and sand-filtered water samples processed during the LBDF yielded any LB. The brooders were found to be the main source of LB as revealed by the rate of isolation of these bacteria during both LBDF and LBD (71-80\% of gills and surface swab samples and $33-59 \%$ of the intestinal and faecal samples). However the LB counts in the gills, intestine and faecal matter during the LBD cycle was significantly high $\left(62-800 \times 10^{4} \mathrm{cfu} \mathrm{ml}^{-1}\right)$, compared to that during LBDF $\left(7.2-320 \times 10^{4} \mathrm{cfu} \mathrm{ml}^{-1}\right)$. A large percentage of water samples from the 
Table 1

Occurrence of luminescent bacteria during luminescent bacterial disease-free larval production cycle (LBDF) and Luminescent bacterial disease-affected larval production cycle (LBD) in a commercial shrimp hatchery

\begin{tabular}{|c|c|c|c|c|c|c|c|c|c|c|}
\hline \multirow[t]{2}{*}{ Source } & \multicolumn{5}{|l|}{ LBDF } & \multicolumn{5}{|l|}{ LBD } \\
\hline & $\begin{array}{l}\text { No. } \\
\text { processed }\end{array}$ & $\begin{array}{l}\text { No. } \\
\text { positive }\end{array}$ & $\begin{array}{l}\text { Range no. } \times \\
10^{4} \mathrm{cfu} \mathrm{ml}^{-1}\end{array}$ & $\begin{array}{l}\text { Average no. } \times \\
10^{4} \mathrm{cfu} \mathrm{ml}^{-1}\end{array}$ & $\begin{array}{l}\text { Percentage of } \\
\text { samples positive } \\
\text { for LB }\end{array}$ & $\begin{array}{l}\text { No. } \\
\text { processed }\end{array}$ & $\begin{array}{l}\text { No. } \\
\text { positive }\end{array}$ & $\begin{array}{l}\text { Range no. } \times \\
10^{4} \mathrm{cfu} \mathrm{ml}^{-1}\end{array}$ & $\begin{array}{l}\text { Average no. } \times \\
10^{4} \mathrm{cfu} \mathrm{ml}^{-1}\end{array}$ & $\begin{array}{l}\text { Percentage of } \\
\text { samples positive } \\
\text { for LB }\end{array}$ \\
\hline \multicolumn{11}{|c|}{ I. Hatchery water source } \\
\hline i. Seawater Source & 45 & 0 & - & - & 0 & 25 & 4 & 0.002 to 0.023 & 0.13 & 16 \\
\hline ii Sand-filtered water & 45 & 0 & - & - & 0 & 25 & 1 & 0.003 & 0.003 & 4 \\
\hline \multicolumn{11}{|l|}{ II. Brooders } \\
\hline i. Surface & 13 & 10 & - & - & 77 & 10 & 8 & - & - & 80 \\
\hline ii. Gills* & 7 & 5 & 7.2 to 320 & 40 & 71 & 5 & 4 & 62 to 790 & 220 & 80 \\
\hline iii. Intestine* & 6 & 2 & 1.2 to 180 & 30 & 33 & 10 & 4 & 70 to 560 & 140 & 40 \\
\hline iv. Feacal matter* & 4 & 2 & 8 to 19 & 13 & 50 & 17 & 10 & 120 to 800 & 320 & 59 \\
\hline \multicolumn{11}{|c|}{ III. Maturation and spawning } \\
\hline $\begin{array}{l}\text { i. Maturation tank } \\
\text { water }\end{array}$ & 5 & 1 & 52 & 52 & 20 & 11 & 8 & 17 to 290 & 260 & 73 \\
\hline $\begin{array}{l}\text { ii. Spawning tank } \\
\text { water }\end{array}$ & 25 & 8 & 0.7 to 250 & 17 & 32 & 15 & 12 & 9 to 590 & 92 & 80 \\
\hline iii. Eggs & 5 & 0 & - & - & 0 & 10 & 0 & - & - & 0 \\
\hline \multicolumn{11}{|l|}{ IV. Feeds } \\
\hline i. Algal culture & 30 & 0 & - & - & 0 & 12 & 1 & 0.2 & 0.02 & 8 \\
\hline ii. Artemia tank & 60 & 0 & - & - & 0 & 0 & 0 & - & - & - \\
\hline \multicolumn{11}{|l|}{ V. Larval rearing tanks } \\
\hline i. Nauplii & 15 & 0 & - & - & 0 & 10 & 0 & - & - & 0 \\
\hline ii. Nauplii tank water & 40 & 0 & - & - & 0 & 18 & 3 & 0.002 to 0.03 & 0.02 & 17 \\
\hline iii. Zoea & 15 & 0 & - & - & 0 & 10 & 1 & 0.0011 & 0.11 & 10 \\
\hline iv. Zoea tank water & 180 & 11 & 0.012 to 0.56 & 0.9 & 6 & 60 & 42 & 0.18 to 42 & 3 & 70 \\
\hline v. Mysis & 20 & 2 & 0.18 to 0.28 & 0.23 & 10 & 12 & 8 & 6.2 to 79 & 56 & 67 \\
\hline vi. Mysis tank water & 100 & 11 & 0.80 to 32 & 1.4 & 11 & 40 & 26 & 1.6 to 29 & 12 & 65 \\
\hline vii. Post larvae -14 & 40 & 10 & 0.16 to 9.30 & 1.5 & 25 & 10 & 9 & 1.7 to 198 & 36 & 90 \\
\hline $\begin{array}{l}\text { viii. Post larval tank } \\
\text { water }\end{array}$ & 202 & 18 & 0.12 to 8.20 & 4.2 & 9 & 38 & 35 & 7.2 to 67 & 26 & 92 \\
\hline Grand Total & 857 & 80 & - & & 9 & 338 & 176 & - & - & 52 \\
\hline
\end{tabular}

$*_{\text {cfu }} \mathrm{g}^{-1}$ of sample.

maturation and spawning tanks ( $73 \%$ and $80 \%$ respectively) during the LBD cycle had significantly high counts of LB $\left(17-290 \times 10^{4}\right.$ and $9-590 \times 10^{4} \mathrm{cfu} \mathrm{ml}^{-1}$ respectively). The algal culture tanks did not harbour any LB during LBDF cycle, whereas only one of the 12 samples from algal culture tanks analysed during LBD affected cycle had LB.

LB could be recovered from $17 \%$ of nauplius tank water samples which subsequently developed luminescent bacterial disease during the mysis stage. Prior to the onset of LB disease, LB could be found in $70 \%$ of the tank water samples during the protozoeal stage with considerably high counts ranging from 0.18 to $42 \times 10^{4} \mathrm{cfu} \mathrm{ml}^{-1}$ (with averages of $3-56 \times 10^{4} \mathrm{cfu} \mathrm{ml}^{-1}$ ). In the LBDF cycle, LB could not be isolated from the nauplii up to zoea stage. However, LB could be isolated from 6 to $25 \%$ of the tank water samples during the protozoeal through PL stages, although in low counts (averages of $0.2-4.2 \times 10^{4} \mathrm{cfu} \mathrm{ml}^{-1}$ ).

\subsection{Phenotypic characteristics of luminescent bacteria}

Ninety seven luminescent bacteria isolated during the study were subjected to detailed phenotypic characterization. All the isolates were gram negative, oxidase positive. Ninety-four percent of the isolates grew well in $8 \% \mathrm{NaCl}$ and none of the isolates could grow in $0 \% \mathrm{NaCl}$ concentration. None of the isolates produced acetyl methyl carbinol. All the isolates fermented glucose and mannitol while $28 \%$ of the isolates could ferment sucrose. None of the isolates could produce acid by the fermentation of arabinose, lactose and inositol. $86 \%$ of the isolates produced indole and all the isolates tested were able to use cellobiose as the sole source of carbon. Among the 97 isolates, 89 belonged to $V$. harveyi and others to $V$. splendidus (3), V. logei (2), V. fischeri (2) and Photobacterium sp. (1).

\subsection{Isolation of bacteriophages from water samples}

Out of a total of 181 samples comprising water samples from seawater source, maturation tanks, spawning tanks and larval rearing tanks, 65 bacteriophages capable of infecting luminescent $V$. harveyi isolates were recovered (Table 2). Thirteen bacteriophages on eight $V$. harveyi hosts were isolated during LBDF cycle and 52 bacteriophages were isolated on $24 \mathrm{~V}$. harveyi hosts during LBD (Table 2). Based on the morphology of the plaques, the phages were categorized in to seven types (Table 3). A total of 28 phages of plaque morphologies of types II, III, IV and VI could be isolated from various samples in the hatchery only during LBD.

Maturation tank water samples were found to be the main source of bacteriophages, $52 \%$ and $90 \%$ of these samples had bacteriophages 
Table 2

Isolation of bacteriophages of luminescent $V$. harveyi during luminescent bacterial disease-free shrimp larval production cycle (LBDF) and luminescent bacterial disease outbreak affected cycle (LBD) from a commercial shrimp hatchery

\begin{tabular}{|c|c|c|c|c|c|c|c|}
\hline \multirow[t]{2}{*}{ S1.No } & \multirow[t]{2}{*}{ Host } & \multicolumn{3}{|l|}{ LBDF } & \multicolumn{3}{|l|}{ LBD } \\
\hline & & $\begin{array}{l}\text { Phages } \\
\text { isolated }\end{array}$ & pfu $\mathrm{ml}^{-1}$ & $\begin{array}{l}\text { Plaque } \\
\text { Type }\end{array}$ & $\begin{array}{l}\text { Phages } \\
\text { isolated }\end{array}$ & pfu $\mathrm{ml}^{-1}$ & $\begin{array}{l}\text { Plaque } \\
\text { Type }\end{array}$ \\
\hline 1 & Vh01 & P01 & 138 & I & P32 & 112 & I \\
\hline 2 & Vh09 & P05 & 45 & V & - & - & - \\
\hline 3 & Vh10 & P06 & 140 & VII & - & - & - \\
\hline 4 & & P07 & 26 & $\mathrm{~V}$ & - & - & - \\
\hline 5 & Vh11 & P08 & 58 & VII & P44 & 726 & II \\
\hline 6 & - & - & - & - & P49 & 164 & III \\
\hline 7 & - & - & - & - & P54 & 960 & I \\
\hline 8 & Vh13 & P09 & 246 & $\mathrm{~V}$ & P48 & 518 & II \\
\hline 9 & & P14 & 154 & V & P60 & 532 & $\mathrm{~V}$ \\
\hline 10 & & P15 & 160 & VII & P63 & 48 & IV \\
\hline 11 & & & & & P65 & 516 & III \\
\hline 12 & Vh14 & P10 & 206 & VII & P62 & 438 & VI \\
\hline 13 & Vh16 & P13 & 118 & I & - & - & - \\
\hline 14 & & P52 & 126 & $\mathrm{~V}$ & - & - & - \\
\hline 15 & & P59 & 230 & VII & - & - & - \\
\hline 16 & Vh21 & P11 & 242 & I & P37 & 560 & $\mathrm{~V}$ \\
\hline 17 & & & & & P38 & 620 & VII \\
\hline 18 & Vh26 & - & - & - & P12 & 710 & $\mathrm{~V}$ \\
\hline 19 & Vh29 & - & - & - & P35 & 820 & VII \\
\hline 20 & & - & - & - & P46 & 830 & III \\
\hline 21 & & - & - & - & P50 & 740 & $\mathrm{~V}$ \\
\hline 22 & & - & - & - & P57 & 169 & II \\
\hline 23 & & - & - & - & P58 & 267 & VII \\
\hline 24 & & - & - & - & P61 & 172 & VI \\
\hline 25 & Vh30 & - & - & - & P36 & 167 & III \\
\hline 26 & & - & - & - & P45 & 169 & $\mathrm{~V}$ \\
\hline 27 & & - & - & - & P47 & 226 & VII \\
\hline 28 & & - & - & - & P51 & 176 & II \\
\hline 29 & & - & - & - & P55 & 522 & $\mathrm{~V}$ \\
\hline 30 & & - & - & - & P56 & 396 & VII \\
\hline 31 & & - & - & - & P64 & 165 & $\mathrm{~V}$ \\
\hline 32 & Vh44 & - & - & - & P16 & 218 & $\mathrm{~V}$ \\
\hline 33 & & - & - & - & P18 & 242 & III \\
\hline 34 & Vh45 & - & - & - & P17 & 286 & VII \\
\hline 35 & Vh49 & - & - & - & P19 & 166 & III \\
\hline 36 & Vh51 & - & - & - & P02 & 182 & II \\
\hline 37 & & - & - & - & P43 & 193 & III \\
\hline 38 & Vh54 & - & - & - & P21 & 182 & $\mathrm{~V}$ \\
\hline 39 & Vh57 & - & - & - & P20 & 194 & III \\
\hline 40 & Vh84 & - & - & - & P41 & 320 & $\mathrm{~V}$ \\
\hline 41 & & - & - & - & P42 & 418 & $\mathrm{~V}$ \\
\hline 42 & Vh93 & - & - & - & P23 & 456 & III \\
\hline 43 & Vh94 & - & - & - & P26 & 326 & IV \\
\hline 44 & Vh95 & - & - & - & P25 & 226 & $\mathrm{~V}$ \\
\hline 45 & Vh97 & - & - & - & P24 & 423 & III \\
\hline 46 & Vh99 & - & - & - & P22 & 424 & VI \\
\hline 47 & & - & - & - & P39 & 510 & $\mathrm{~V}$ \\
\hline 48 & Vh100 & - & - & - & P27 & 256 & III \\
\hline 49 & & - & - & - & P28 & 412 & IV \\
\hline 50 & Vh101 & - & - & - & P40 & 452 & VI \\
\hline 51 & Vh102 & - & - & - & P03 & 690 & III \\
\hline 52 & & - & - & - & P29 & 182 & VII \\
\hline 53 & & - & - & - & P30 & 422 & $\mathrm{~V}$ \\
\hline 54 & & - & - & - & P33 & 329 & III \\
\hline 55 & & - & - & - & P53 & 150 & VII \\
\hline 56 & Vh105 & - & - & - & P04 & 184 & IV \\
\hline 57 & & - & - & - & P31 & 30 & VI \\
\hline 58 & & - & - & - & P34 & 600 & III \\
\hline Total & 27 & 13 & - & - & 52 & - & - \\
\hline
\end{tabular}

affecting $V$. harveyi during LBDF and LBD respectively, with a relatively higher pfu, compared to that in the other sources. The bacteriophage counts in the maturation tanks, prior to the incidence of LBD in larval shrimp were also found to be relatively higher (164$960 \mathrm{pfu} \mathrm{ml}^{-1}$ ), whereas, their populations during the LBDF were relatively low and ranged from 26 to $246 \mathrm{pfu} \mathrm{ml}^{-1}$. Similarly spawning tank water samples were also found to be important sources of bacteriophages of $V$. harveyi (Table 4). Bacteriophages of $V$. harveyi could also be recovered from the larval rearing tanks (LRTs) during LBD, although from a lesser percentage $(7 \%)$ of the samples. We could not recover any bacteriophages from LRTs during LBDF. The bacteriophage count was found to be positively correlated with the luminescent bacterial counts in all these samples $(P=0.288$ at $0.05 \%$ significance level during disease outbreak and $P=0.809$ at $0.01 \%$ significance level during LBDF) (Fig. 1).

\section{Discussion}

The present study deals with the distribution of luminescent bacteria and their bacteriophages during various stages of shrimp larval production in a commercial hatchery. This study was carried out during February and May 2006, and LB disease was noticed in the month of May 2006 during mysis stage. Of the 1195 samples comprising brooders, water from maturation, spawning and larval rearing tanks, eggs, nauplii, zoea and mysis, luminescent bacteria could be isolated from $21 \%$ of the samples. However, an earlier similar study (Abraham and Palaniappan, 2004) reported a higher rate of isolation of luminescent bacteria (59.68\%) from samples including source water, eggs, broodstock, larvae, larval rearing tank water, algal culture tanks, Artemia nauplii and swab samples from water distribution systems in P. indicus and P. monodon hatcheries of Tamil Nadu, India.

Near shore water was reported to be one of the main sources of $V$. harveyi infection in $P$. monodon hatcheries in the Philippines (Lavilla-Pitogo et al., 1992). However in the present study luminescent bacteria could be isolated from only $16 \%$ of source water samples during LBD and could not be isolated during LBDF in shrimp hatchery. The intake water was filtered through sand filters, followed by chlorination providing some

Table 3

Morphology of $V$. harveyi bacteriophages recovered during luminescent bacterial disease-free shrimp larval production cycle (LBDF) and luminescent bacterial disease outbreak affected cycle (LBD) from a commercial shrimp hatchery

\begin{tabular}{|c|c|c|c|c|}
\hline $\begin{array}{l}\text { Plaque } \\
\text { type }\end{array}$ & Plaque morphology & LBDF & LBD & Total \\
\hline Type I & Pinpoint, clear centered, irregular margin & 3 & 2 & 5 \\
\hline Type II & $0.5-1.5 \mathrm{~mm}$, opalescent, irregular margin & - & 5 & 5 \\
\hline Type III & $1-2 \mathrm{~mm}$, clear centered, irregular margin & - & 14 & 14 \\
\hline Type IV & $\begin{array}{l}\text { Pinpoint to } 1 \mathrm{~mm} \text {, opalescent, irregular } \\
\text { margin }\end{array}$ & - & 3 & 3 \\
\hline Type V & $\begin{array}{l}2-3.5 \mathrm{~mm} \text {, clear centered, irregular, hazy } \\
\text { margin }\end{array}$ & 5 & 14 & 19 \\
\hline Type VI & $1-1.5 \mathrm{~mm}$, clear centered, entire margin & - & 6 & 6 \\
\hline \multirow[t]{2}{*}{ Type VII } & $\begin{array}{l}1.5-2 \mathrm{~mm} \text {, clear centered, regular, hazy } \\
\text { margin }\end{array}$ & 5 & 8 & 13 \\
\hline & Total & 13 & 52 & 65 \\
\hline
\end{tabular}


Table 4

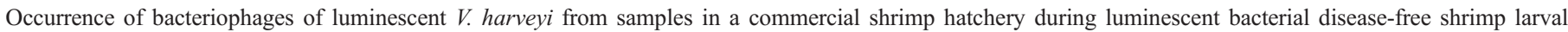
production cycle (LBDF) and luminescent bacterial disease outbreak affected cycle (LBD)

\begin{tabular}{|c|c|c|c|c|c|c|c|c|c|}
\hline \multirow[t]{2}{*}{ S.No } & \multirow[t]{2}{*}{ Source } & \multicolumn{4}{|l|}{ LBDF } & \multicolumn{4}{|l|}{ LBD } \\
\hline & & No. processed & No. positive & $\begin{array}{l}\text { Phage counts } \\
\text { pfu } \mathrm{ml}^{-1}\end{array}$ & Average pfu & No. processed & No. positive & $\begin{array}{l}\text { Phage counts } \\
\text { pfu } \mathrm{ml}^{-1}\end{array}$ & Average pfu \\
\hline 1 & Source water & 20 & 0 & 0 & 0 & 20 & $2(10)$ & $30-150$ & 90 \\
\hline 2 & Maturation tank & 21 & $11(52)$ & $45-246$ & 167 & 40 & $36(90)$ & $164-960$ & 401 \\
\hline 3 & Spawning tank & 10 & $2(20)$ & $26-126$ & 76 & 30 & $12(40)$ & $112-726$ & 385 \\
\hline \multirow[t]{2}{*}{4} & Larval rearing tank & 10 & 0 & 0 & 0 & 30 & $2(7)$ & $48-165$ & 106.5 \\
\hline & Total & 61 & $13(21)$ & - & - & 120 & $52(43)$ & - & - \\
\hline
\end{tabular}

Figures in parenthesis in percentage.

advantageous effect in reducing the load of $V$. harveyi in the hatchery.

The shrimp brooders used in the hatchery were obtained from offshore water of Andamans and southern Bay of Bengal, and were found to be the main source of luminescent bacteria as revealed by their occurrence in $77 \%$ and $80 \%$ of the surface samples and $71 \%$ and $80 \%$ gill samples during LBDF and LBD respectively. Formation of biofilm on the surfaces in hatchery systems appears to be an important trait of luminescent bacteria helping them in persisting in the hatchery systems (Karunasagar and Otta, 1996; Abraham and Palaniappan, 2004). The gut content of brood shrimp were also found to be an important source of luminescent bacteria as revealed in earlier studies (Hasting and Nealson, 1981). $V$. harveyi are known to enter and traverse the digestive tract and survive the digestive process of marine fishes and proliferate extensively in the faecal matter and distribute into the surrounding sea water (Ruby and Morin, 1979). After excretion, the luminescent bacteria proliferate in the faecal matter and with the help of other organic matter such as the uneaten feed in the maturation and spawning tanks.

Although the occurrence of luminescent bacteria was more frequent in the maturation and spawning tanks, we could not recover any luminescent bacteria from eggs and nauplii. The eggs were washed with iodine and formalin soon after collection as a management practice in the hatchery, which appear to help a great deal in their containment after spawning. The fact that LB could not be recovered from eggs and nauplii poses questions on their occurrence in the nauplii tank water samples (during the seed production cycle affected by LB disease) and zoea stage onwards (during the seed production cycle free from LB disease) and subsequent larval stages. This may be possibly due to presence of low counts of LB in eggs and nauplii, which could not be detected by the methods used $(0.1 \mathrm{~g}$ of egg/nauplii biomass and $1 \mathrm{ml}$ of water samples used for isolation of LB by serial dilution and spread plate technique). Another plausible reason could be existence of LB in "viable but non-culturable" state (Roszak and Colwell, 1987) followed by their resuscitation in the tanks during the subsequent larval developmental stages (Ramaiah et al., 2002).

Analysis of samples in the post-hatching sections has yielded interesting results. Total mortality of shrimp larvae was observed in larval production cycle affected with luminescent bacterial disease by PL6 stage. Survival rate at PL14 was 80\% during LBDF. During the larval production cycle affected by luminescent bacterial disease, colonization of protozoeal stages with luminescent bacteria preceded their occurrence in the LRT water samples during the nauplius stage. Further when we examine the two situations, viz., LBD and LBDF, occurrence and multiplication of

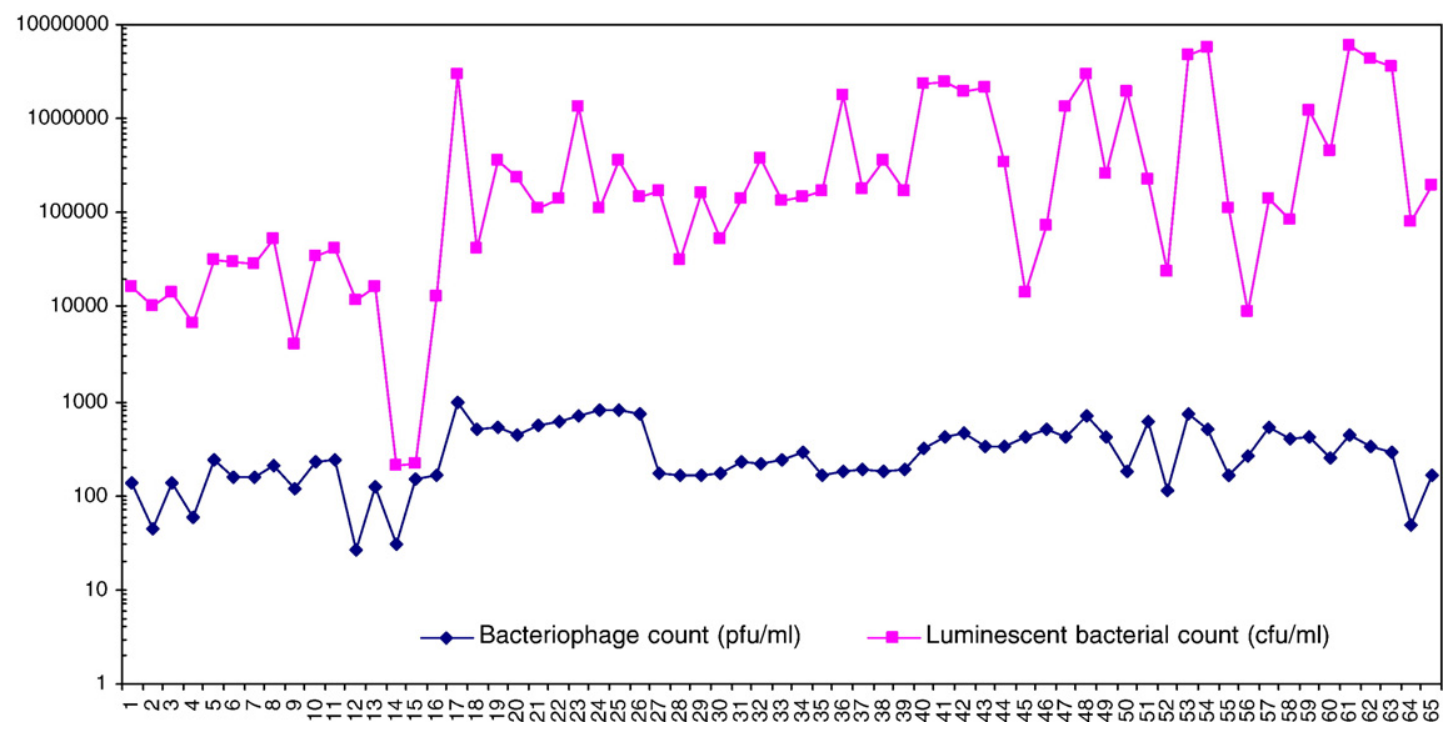

Fig. 1. Relative count of luminescent $V$. harveyi and associated bacteriophages in shrimp hatchery samples. 
luminescent bacteria occurred in an exponential phase during the LBD, with corresponding drop in survival of affected larval shrimp. The observation suggests that the occurrence of luminescent bacteria during nauplii stage in the rearing tank water could be an indicator of impending luminescent bacterial disease outbreak in the larval rearing tanks and possibly help in the prognosis of LBD.

Although earlier studies reported the occurrence of luminescent bacterium in Artemia and Artemia hatching water (Abraham and Palaniappan, 2004; Vaseeharan and Ramasamy, 2003) we could not recover any luminescent bacteria from these samples. Similarly, the algal cultures did not contribute luminescent bacteria to the larval rearing tanks as reported by Lavilla-Pitogo et al. (1992). Abraham and Palaniappan (2004) suggested that the low incidence of luminescent bacteria in Chaetoceros cultures may be due to the antibacterial activity of this diatom.

The observations made in the present study that, luminescent $V$. harveyi could be isolated during all the three cycles of seed production, particularly during protozoea and PL stages, and why the disease outbreak occurred in only one seed production cycle remains to be explored further. Manefield et al. (2000) suggested that virulence associated with extracellular protein and luminescence in $V$. harveyi are co regulated, and their intracellular signal antagonist such as halogenated furanone inhibited concurrent expression of luminescence and toxin production. However, the results obtained in this study do not suggest that luminescence and virulence may be interdependent in $V$. harveyi.

Sixty five phages capable of infecting $V$. harveyi were recovered during the three larval production cycles. The shrimp broodstock maturation tanks were also found to be the main source of bacteriophages of luminescent bacteria. Recovery of bacteriophages of luminescent $V$. harveyi recorded in the present study in maturation and larval rearing tanks suggests existence of a mechanism of natural biocontrol of luminescent bacteria in shrimp hatchery systems. Bacteriophages of $V$. harveyi, belonging to Siphoviridae family have been isolated and described by Pasharawipas et al. (2005) and Vinod et al. (2006). It was also reported that the shrimp larval survival in the presence of the bactriophage was enhanced by $80 \%$ and brought about a decline in the luminescent $V$. harveyi in the hatchery tanks (Vinod et al., 2006). Occurrence of bacteriophages and luminescent $V$. harveyi observed in the present study indicates that there exists a tremendous scope in harnessing bacteriophages for biocontrol of luminous vibriosis in the shrimp hatcheries. It has been reported that there exists a high abundance of free viruses in the aquatic ecosystem (Bergh et al., 1989) and are considered important agents of mortality of bacteria and even influence microbial community composition in the natural marine ecosystem (Fuhrman and Schwalbach, 2003). This report is substantiated by a positive correlation between the bacteriophage counts and LB counts in the hatchery water samples. Despite this positive correlation and the presence of bacteriophages in the hatchery systems observed in the present study, luminescent bacterial diseaseaffected larval shrimp during one cycle. The luminescent strains causing such outbreak in larval stages in the hatchery are possibly contaminants from the maturation and spawning facilities. Option of inoculation of larval rearing tanks with bactriophages isolated on luminescent bacterial hosts recovered from maturation and spawning facilities and early larval stages, as phage therapy remains to be explored for combating luminescent bacterial disease problems in shrimp hatcheries.

Virulence of a number of medically important bacterial pathogens such as V. cholerae, Clostridium botulinum, C. diphtheriae etc., has been proved to be mediated by bacteriophages (Wagner and Waldor, 2002). Similarly, V. harveyi myovirus like (VHML) particles are reported to be associated with virulence in $V$. harveyi (Munro et al., 2003). Nine (5 isolates recovered from infected larvae and 4 from water samples) of $V$. harveyi isolates obtained during the LB disease outbreak in the present study were screened for VHML by polymerase chain reaction (PCR) (Payne et al., 2004) (data not given) and none of these isolates produced the $900 \mathrm{bp}$ product specific for tail sheeth encoding gene of VHML (instead, a $350 \mathrm{bp}$ fragment could be amplified). Occurrence of luminous vibriosis in larval shrimp by LB isolates that lack VHML suggests possibilities of involvement of other bacteriophages similar to VHML in the virulence of $V$. harveyi. This argument may be substantiated by the observations that phages with near identical genomes are rarely isolated from independent sources in nature (Casjens et al., 1992). Hence, further studies would be required to explore the role of bacteriophages in the virulence of $V$. harveyi.

\section{Conclusion}

The study has indicated that the shrimp brooders are the main source of luminescent bacteria in the shrimp hatcheries. Good management practices such as egg washing helps in the elimination of luminescent bacteria in the larval rearing tanks. Presence of luminescent $V$. harveyi during nauplius and protozoeal stages could indicate impending luminescent bacterial disease outbreak in the subsequent larval stages of shrimp in the hatchery. The study has also indicated that the bacteriophages occur predominantly in the shrimp broodstock maturation and spawning facilities in the shrimp hatchery and co-exist with the luminescent $V$. harveyi. Reasons for the outbreak of luminescent bacterial disease in the larval shrimp despite presence of bacteriophages in the larviculture systems remain to be explored.

\section{Acknowledgements}

Authors are thankful to the Indian Council of Agricultural Research (ICAR), New Delhi for the financial assistance in carrying out this study (F.No.4 (57/2004-ASR-I). Authors are also indebted to the management and staff of the Oceanic Shrimping Ltd, Chennai for providing samples and basic facilities in conducting this study. Authors also thank Dr. A. G. Ponniah, Director, Central Institute of Brackishwater Aquaculture for critical evaluation of this work.

\section{References}

Abraham, T.J., Palaniappan, R., 2004. Distribution of luminous bacteria in semiintensive penaeid shrimp hatcheries of Tamil Nadu, India. Aquaculture 232, $81-90$. 
Ackermann, H.W., 1996. Frequency of morphological phage descriptions in 1995. Arch. Virol. 141, 209-218.

Alsina, M., Blanch, A.R., 1994. A set of keys for biochemical identification of environmental Vibrio species. J. Appl. Bacteriol. 76, 79-85.

Alvarez, J.D., Austin, B., Alvarez, A.M., Reyes, H., 1998. Vibrio harveyi: a pathogen of penaeid shrimps and fish in Venezuela. J. Fish Dis. 21, 313-316.

Baticados, M.C.L., Lavilla Pitogo, C.R., Cruz Lacierda, E.R., Pena, L.D.d.1., Sunaz, N.A., 1990. Studies on the chemical control of luminous bacteria Vibrio harveyi and V. splendidus isolated from diseased Penaeus monodon larvae and rearing water. Dis. Aquat. Org. 9, 133-139.

Baumann, P., Schubert, R.H.W., 1984. Family II: Vibrionceae, Veron 1965. In: Krieg, N.R., Holt, J.G. (Eds.), Bergey's Manual of Systematic Bacteriology. Williams and Wilkins, Baltimore, USA, pp. 516-550.

Bergh, O., Børsheim, K.Y., Bratbak, G., Heldal, M., 1989. High abundance of viruses found in aquatic environments. Nature 340, 467-468.

Carlson, K., 2005. Working with bacteriophages, common techniques and methodological approaches. In: Kutter, E., Sulakvaelidze, A. (Eds.), Bacteriophages: Biology and Applications. CRC Press, USA, Washington DC, pp. 437-494.

Casjens, S., Sampson, L., Randall, S., Eppler, K., Wu, H., Petri, J.B., Schmieger, H., 1992. Molecular genetic analysis of bacteriophage $\mathrm{P} 22$ gene 3 product, a protein involved in the initiation of headful DNA packaging. J. Mol. Biol. 227, 1086-1099.

Fuhrman, J.A., Schwalbach, M., 2003. Viral influence on aquatic bacterial communities. Biol. Bull. 204, 192-195.

Harris, L., Owens, L., Smith, S., 1996. A selective and differential medium for Vibrio harveyi. Appl. Environ. Microbiol. 62, 3548-3550.

Hasting, J.W., Nealson, K., 1981. The symbiotic luminous bacteria. In: Starr, M., Trueper, H., Balows, A.A., Schlegel, H. (Eds.), The Prokaryotes: A Handbook on Habitats, Isolation and Identification of Bacteria. SpringerVerlag, Berlin, pp. 1322-1345.

Jiravanichpaisal, P., Miyazaki, T., Limsuwan, C., 1994. Histopathology, biochemistry, and pathogenicity of Vibrio harveyi infecting black tiger prawn Penaeus monodon. J. Aquat. Anim. Health 6, 27-35.

Karunasagar, I., Otta, S.K., 1996. Biofilm formation by Vibrio harveyi on surfaces. Aquaculture 140, 241-245.

Karunasagar, I., Pai, R., Malathi, G.R., Karunasagar, I., 1994. Mass mortality of Penaeus monodon larvae due to antibiotic-resistant Vibrio harveyi infection. Aquaculture 128, 203-209.

Lavilla-Pitogo, C.R., Baticados, M.C.L., Cruz-lacierda, E.R., De la Pena, L.D., 1990. Occurrence of luminescent bacterial disease of Penaeus monodon larvae in the Phillippines. Aquaculture 91, 1-13.

Lavilla-Pitogo, C.R., Albright, L.J., Panar, M.G., Sunaz, N.A., 1992. Studies on the sources of luminescent Vibrio harveyi in Penaeus monodon hatcheries. In: Shariff, M., Subasinge, R.P., Arthur, J.R. (Eds.), Disease in Asian Aquaculture. Fish Health Section. Asian Fisheries Society, Manila, pp. 157-164.

Liu, P.C., Lee, K.K., Yii, K.C., Kou, G.H., Chen, S.N., 1996. Isolation of Vibrio harveyi from diseased kuruma prawns Penaeus japonicus. Curr. Microbiol. 33, 129-132.

Manefield, M., Harris, L., Rice, S.A., De Nys, R., Kjelleberg, S., 2000. Inhibition of luminescence and virulence in the black tiger prawn (Penaeus monodon) pathogen Vibrio harveyi by intercellular signal antagonists. Appl. Environ. Microbiol. 66, 2079-2084.

Moriarty, D.J.W., 1999. Disease control in shrimp aquaculture with probiotic bacteria. In: Bell, C.R., Brylinsky, M., Johnson-Green, P. (Eds.), Microbial Biosystems: New Frontiers, Proceedings of the 8th International Symposium on Microbial Ecology Atlantic Canada Society for Microbial Ecology, Halifax, Canada.

Munro, J., Oakey, J., Bromage, E., Owens, L., 2003. Experimental bacteriophage-mediated virulence in strains of Vibrio harveyi. Dis. Aquatic Org. 54, 187-194.

Nakai, T., Park, S.C., 2002. Bacteriophage therapy of infectious disease in aquaculture. Res. Microbiol 153, 13-18.
O’ Brien, C.H., Sizemore, R.K., 1979. Distribution of the luminous bacterium Beneckea harveyi in a semitropical estuarine environment. Appl. Environ. Microbiol. 38, 928-933.

Park, K.H., Matsuoka, S., Nakai, T., Muroga, K., 1997. A virulent bacteriophage of Lactococcus garviae (formerly Enterococcus seriolicida) a pathogen of cultured yellow tail. Fish. Sci. 64, 62-64.

Park, S.C., Shimamura, I., Fukunnaga, M., Mori, K., Nakai, T., 2000. Isolation of bacteriophages specific to a fish pathogen, Pseudomonas plecoglossicida, as a candidate for disease control. Appl. Environ. Microbiol. 66, 1416-1422.

Pasharawipas, T., Thaikua, S., Sriurairatana, S., Ruangpan, L., Direkbusarakum, S., Manopvisetcharean, J., Flegel, T.W., 2005. Partial characterization of a novel bacteriophage of Vibrio harveyi isolated from shrimp culture ponds in Thailand. Virus Res. 114, 63-69.

Payne, M., Oakey, J., Owens, L., 2004. The ability of two different Vibrio spp. bacteriophages to infect Vibrio harveyi, Vibrio cholerae and Vibrio mimicus. J. Appl. Microbiol. 97, 663-672.

Pizzutto, M., Hirst, R.G., 1995. Classification of isolates of Vibrio harveyi virulent to Penaeus monodon larvae by protein profile analysis and M13 DNA fingerprinting. Dis. Aquat. Org. 21, 61-68.

Proctor, L.M., Fuhrman, J.A., 1990. Viral mortality of marine bacteria and Cyanobacteria. Nature 343, 60-62.

Ramaiah, N., Chandramohan, D., 1993. Ecological and laboratory studies on the rate of luminous bacteria and their luminescence in coastal pollution surveillance. Marine Poll. Bull. 26, 190-201.

Ramaiah, N., Ravel, J., Straube, W.L., Hill, R.T., Colwell, R.R., 2002. Entry of Vibrio harveyi and Vibrio fischeri into the viable but nonculturable state. J. Appl. Microbiol. 92, 1-9.

Roszak, D.B., Colwell, R.R., 1987. Survival strategies of bacteria in the natural environment. Microbiol. Rev. 51, 365-379.

Ruby, E.G., Morin, J.G., 1979. Luminous enteric bacteria of marine fishes: a study of their distribution, densities and dispersion. Appl. Environ. Microbiol. 38, 406-411.

Schneider, J., Rheinheimer, G., 1988. Isolation Methods. John Miley and Sons, Chichester. 73-94 pp.

Smibert, R.M., Krieg, N.R., 1991. Phenotypic characterization. In: Gerhardt, P., Murray, R.G.E., Costilow, R.N., Nester, E.W., Woods, W.A., Kreig, N.R. (Eds.), Manual of Methods for General and Molecular Biology. American Soceity for Microbilogy, Washington DC, USA, pp. 607-657.

Sulakvelidze, A., Alavize, Z., Morris, J.G.J., 2001. Bacteriophage therapy. Antimicrob. Agents Chemother. 45, 649-659.

Sunaryanto, A., Mariam, A., 1986. Occurrence of a pathogenic bacteria causing luminescence in penaeid larvae in Indonesian hatcheries. Bull. Brackishwater Aquacult. Dev. Centre 8, 64-70.

Suttle, C.A., 1993. Enumeration and isolation of viruses. In: Kemp, P.F., Sherr, B.F., Sherr, E.B., C., J.J. (Eds.), Handbook of Methods in Aquatic Microbial Ecology. Lewis Publishers, USA, pp. 121-134.

Suttle, C.A., 1994. The significance of viruses to mortality in aquatic microbial communities. Microb. Ecol. 28, 237-244.

Suttle, C.A., 2005. Viruses in the sea. Nature. 437, 356-361.

Vaseeharan, B., Ramasamy, P., 2003. Abundance of potentially pathogenic micro-organisms in Penaeus monodon larvae rearing systems in India. Microbiol. Res. 158, 299-308.

Vinod, M.G., Shivu, M.M., Umesha, K.R., Rajeeva, B.C., Krohne, G., Karunasagar, I., Karunasagar, I., 2006. Isolation of Vibrio harveyi bacteriophage with a potential for biocontrol of luminous vibriosis in hatchery environments. Aquaculture 225, 117-124.

Wagner, P.L., Waldor, M.M., 2002. Bacteriophage control of bacterial virulence. Infect. Immun. 70, 3985-3993.

Weinbauer, M.G., 2004. Ecology of prokaryotic viruses. FEMS Microbiol Rev. $28,127-181$.

Yetinson, T., Shilo, M., 1979. Seasonal and geographic distribution of luminous bacteria in the Eastern Mediterranean Sea and the Gulf of Elat. Appl Environ Microbiol. 37, 1230-1238. 